\title{
PENGELOLAAN LINGKUNGAN REHABILITASI DRAINASE PADA IRIGASI GUNUNG NAGO DISEPANJANG JALAN ALAI- BYPASS KOTA PADANG
}

\author{
Nur Taufiq Budi Aji, Bambang Istijono, Yervi Hesna \\ Jurusan Teknik Sipil, Fakultas Teknik, Universitas Andalas \\ email : bistijono1452@yahoo.co.id
}

\begin{abstract}
ABSTRAK
Akibat bencana alam gempa bumi Sumatera Barat 30 September 2009 terjadi kemacetan di sepanjang jalan Alai-Bypass yang berdampingan dengan drainase Irigasi Gunung Nago di Kota Padang. Selanjutnya Pemerintah berkaitan dengan kegiatan mitigasi bencana, membuat jalur evakuasi tsunami dengan melaksanakan pelebaran jalan Alai-Bypass yaitu memperbaiki sistem drainase Irigasi Gunung Nago sepanjang $2 \mathrm{~km}$ dengan penutup beton. Analisa Mengenai Dampak Lingkungan (Amdal) merupakan kajian mengenai dampak besar dan penting suatu kegiatan yang diperlukan sebagai proses pengambilan keputusan. Penerapan dilapangan kajian Amdal pada kegiatan ini belum sepenuhnya diterapkan. Penelitian dilakukan dengan menganalisa dokumen kontrak apakah didalamnya diatur mengenai Amdal, melakukan survai menggunakan pendekatan wawancara dan observasi lapangan untuk mengamati dampak yang terjadi serta mengklasifikasikan dampak yang terjadi.

Hasil penelitian, selama pelaksanaan kegiatan terdapat dampak negatif dan positif. Kegiatan ini tidak sepenuhnya menerapkan kajian Amdal, sehingga terjadi beberapa dampak negatif yang dirasakan masyarakat berupa penurunan kualitas udara 74\%, 100\% masyarakat mengalami kemacetan lalulintas, penurunan kualitas air $65 \%$, penurunan pendapatan masyarakat yang memiliki usaha sebesar 65\%, 81\% aksesibiltas masyarakat terganggu. Sedangkan dampak positif berupa kesempatan kerja bagi masyarakat disekitarnya dan drainase berfungsi optimal. Saran kepada pengambil kebijakan, pada kegiatan yang sifatnya rehabilitasi yang memungkinkan terjadi dampak kepada masyarakat, diperlukan kegiatan Amdal, utamanya kegiatan di perkotaan.
\end{abstract}

Kata kunci: rehabilitasi, drainase, Amdal, dampak positif dan negatif.

\section{ABSTRACT}

The earthquake on 30 September 2009 in West Sumatra has created traffic congestion at Alai-Bypass road in Padang. Along side this road is the irrigation system of Gunung Nago. In order to avoid a traffic congestion in the future and as a part of disaster mitigation activities, the Government decided to widened the road by converting Gunung Nago irrigation system from an open channel into a closed channel. The reinfoced concrete was build at the top of the channel for $2 \mathrm{~km}$ long. Inevitably this project has significant impact on environemnt. However, the implemetaion of Environmental Impact Assessment (Amdal) in the project location has not been fully implemented. The study was conducted by analyzing the contract document whether an Amdal is listed, conducting interviews with community, and field observation to observe the impact of the project to the environment.

It was found that, the project has both negative and positive impacts. As it does not fully implement the Amdal, the negative impacts perceived by the community and the percentage of community suffered from it are as follows: a decrease in air quality $74 \%$, a traffic congestion $100 \%$, a deterioration of water quality $65 \%$, a decrease in trading revenue $65 \%$, an accessibility $81 \%$. While the positive impact is the project created an employment opportunities for communnity and and the irrigation system function optimally. It was suggested that for a project in urban areas that might had a negative impact on community, government should consider the implementation of Amdal..

Keywords: rehabilitation, drainage, EIA, positive and negative effects. 


\section{PENDAHULUAN}

\section{Latar Belakang}

Dalam suatu proyek pembangunan, Amdal sangat diperlukan untuk mengendalikan dampak negatif yang ditimbulkan baik dampak terhadap alam, sosial, dan budaya. Para pemangku kepentingan, yang terdiri dari pemerintah sekaligus pembuat kebijakan, kontraktor sebagai penyedia jasa dan lembaga swadaya masyarakat harus mengawasi kegiatan pembangunan infrasruktur drainase yang dibangun, tidak hanya berfungsi sebagaimana mestinya tapi juga berwawasan lingkungan.

Saat bencana gempa bumi di Sumatera Barat pada tanggal 30 September 2009, terjadi kemacetan parah di sepanjang jalan dari Pasar Alai menuju jalan Bypass di Padang. Pasca bencana pemerintah memerlukan infrastruktur mitigasi bencana dengan membuat jalur evakuasi tsunami yang berdampak pelebaran jalan dengan memperbaiki sistem drainase pada Irigasi Gunung Nago oleh Dinas Pengelolaan Sumber Daya Air Provinsi Sumatera Barat (Gambar 1). Saluran drainase tanah ditingkatkan kapasitas banjirnya dengan saluran pasangan batu dan penutup beton $(2,5 \mathrm{~m} \times 2,5 \mathrm{~m})$. Dinding pasangan batu dilaksanakan secara bertahap dibagian kiri selanjutnya dibagian kanan dan kemudian dikerjakan penutup beton, sehingga air drainase tetap mengalir selama pelaksanaan. Kegiatan rehabilitasi drainase sepanjang $2 \mathrm{~km}$ ini terletak dilingkungan padat penduduk dengan lalulintas padat.

Dalam pelaksanaannya terjadi dampak negatif yang diakibatkan pekerjaan penggalian dan penimbunan seperti debu yang berterbangan, kemacetan arus lalu-lintas, kekeruhan air, aliran air bersih mati dan dampak negatif lainnya.

Pemerintah banyak mengeluarkan peraturan dan pedoman yang mengatur masalah Amdal, di lapangan peraturan tersebut dimasukkan dalam pasal syarat-syarat kontrak, sebagai pedoman pelaksanaan pekerjaan.

Penelitian ini melakukan analisa penerapan Amdal pada pekerjaan rehabilitasi drainase pada Irigasi Gunung Nago disepanjang jalan Alai-Bypass di Padang.

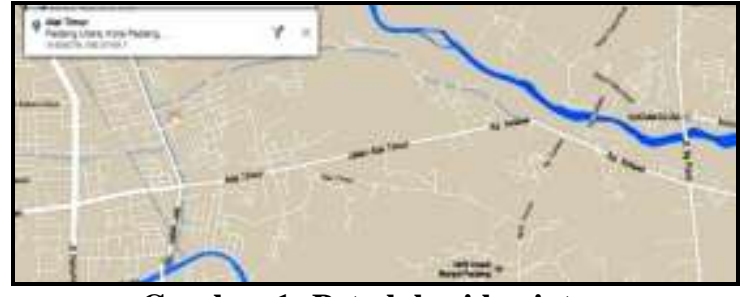

Gambar 1: Peta lokasi kegiatan

\section{Tujuan}

Penelitian ini bertujuan :

- Mengetahui upaya pembangunan yang berwawasan lingkungan.

- Mengetahui dampak pembangunan yang ditimbulkan terhadap lingkungan dan masyarakat.

- Mengetahui proses pengendalian dampak negatif yang ditimbulkan suatu pekerjaan.

\section{METODOLOGI}

Penelitian dilaksanakan dengan menganalisa dampak lingkungan kegiatan pekerjaan rehabilitasi drainase pada jalan Alai-Bypass didasari dengan Keputusan Menteri Negara Lingkungan Hidup Nomor 17 tahun 2001 tentang Jenis usaha dan/atau kegiatan yang wajib dilengkapi dengan Amdal. Pengumpulan data dilakukan pada bulan Mei-Juli 2014 dengan metode survey lapangan dan wawancara. Panduan wawancara seperti yang terlihat pada Tabel 1. Untuk dapat mengetahui hal tersebut dilakukan penelitian dengan menganalisa dokumen kontrak apakah didalamnya diatur hal mengenai Amdal, juga melakukan observasi lapangan yang bertujuan untuk mengamati dampak yang terjadi secara langsung serta mengklasifikasikan dampak yang terjadi selama pekerjaan dilaksanakan, dengan menggunakan pendekatan wawancara kepada masyarakat (Tabel 1 dan Gambar 2), yang dirumuskan berdasarkan hasil observasi lapangan mengenai dampak yang terjadi. Pengambilan bukti berupa dokumentasi dampak aktual yang terjadi pada saat kegiatan sedang berlangsung. 
Tabel 1: Daftar pertanyaan dan wawancara

\begin{tabular}{|c|c|c|c|}
\hline \multirow{2}{*}{ No. } & \multirow{2}{*}{ Pertanyaan } & \multicolumn{2}{|c|}{ Jawaban } \\
\hline & & Ada & Tidak \\
\hline 1 & $\begin{array}{l}\text { Apakah ada dampak negatif dari pelaksanaan rehabilitasi drainase } \\
\text { irigasi pada jalan Alai-Bypass? }\end{array}$ & & \\
\hline 2 & $\begin{array}{l}\text { Apakah ada dampak positif dari pelaksanaan rehabilitasi drainase } \\
\text { irigasi pada jalan Alai-Bypass? }\end{array}$ & & \\
\hline 3 & Apakah ada peningkatan kesejahteraan selama kegiatan berlangsung? & & \\
\hline 4 & $\begin{array}{l}\text { Apakah pada saat pelaksanaan pekerjaan mengganggu aktivitas } \\
\text { masyarakat? }\end{array}$ & & \\
\hline 5 & Hal buruk apa saja yang terjadi selama masa konstruksi? & & \\
\hline 6 & Hal baik apa saja yang terjadi selama masa konstruksi? & & \\
\hline 7 & $\begin{array}{l}\text { Apa saja keluhan masyarakat pada pekerjaan drainase irigasi di jalan } \\
\text { Alai-Bypass? }\end{array}$ & & \\
\hline 8 & $\begin{array}{l}\text { Apakah pekerjaan ini memiliki kontribusi terhadap rehabilitasi } \\
\text { lingkungan? }\end{array}$ & & \\
\hline 9 & Apakah ada upaya untuk mengatasi kerugian yang ditimbulkan? & & \\
\hline 10 & $\begin{array}{l}\text { Apakah kegiatan pekerjaan ini kedepan menguntungkan bagi } \\
\text { masyarakat yang berada di sekitar drainase? }\end{array}$ & & \\
\hline
\end{tabular}

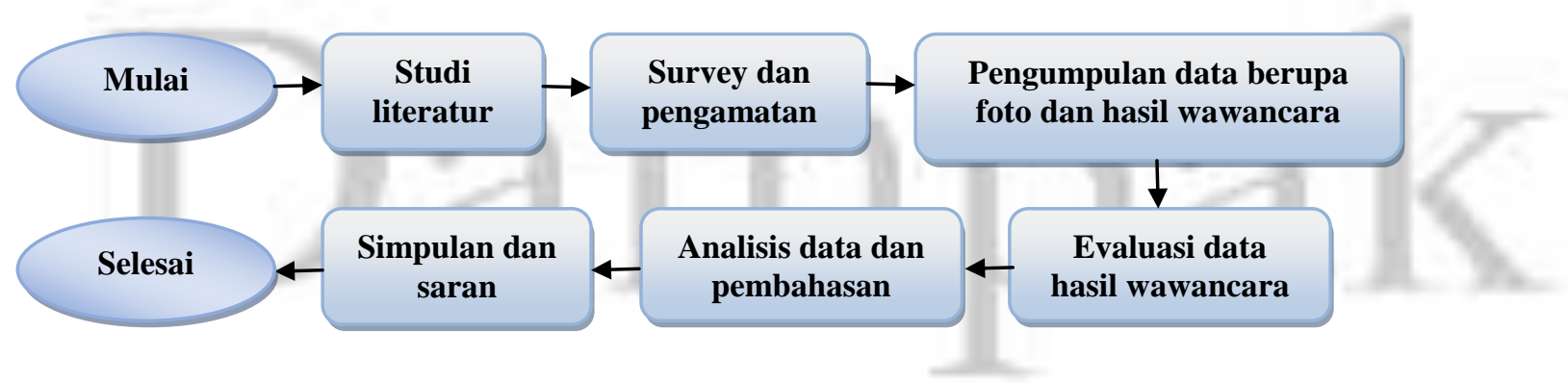

Gambar 2 : Bagan alur penelitian

\section{HASIL DAN PEMBAHASAN}

\section{Peran Amdal pada pekerjaan rehabilitasi drainase Irigasi Gunung Nago}

Setelah menganalisa dokumen kontrak pada Dinas Pengelolaan Sumber Daya Air, tidak ditemukan hal yang mengatur tentang pembangunan yang berwawasan lingkungan atau dokumen Amdal di dalamnya.

Pada dokumen kontrak hanya membahas pemeliharaan lingkungan pada Syarat-Syarat Umum Kontrak No. 45 dengan judul selengkapnya Pemeliharan Lingkungan "Penyedia berkewajiban untuk mengambil langkah-langkah yang memadai untuk melindungi lingkungan baik di dalam maupun di luar tempat kerja dan membatasi gangguan lingkungan terhadap pihak ketiga dan harta bendanya sehubungan dengan pelaksanaan".

\section{Hasil wawancara kepada masyarakat}

Wawancara dengan warga yang bertempat tinggal di kawasan lingkungan kegiatan dan dipilih merata dengan jumlah narasumber 50 orang. Proses wawancara dengan mengajukan 10 pertanyaan kepada masing-masing narasumber. Berikut adalah pertanyaan beserta hasil dari wawancara dimaksud. 
1. Apakah ada dampak negatif dari pelaksanaan rehabilitasi drainase irigasi pada jalan Alai-Bypass?

Hasil wawancara kepada 50 narasumber, 43 orang menjawab ada dan 7 orang menjawab tidak ada (Gambar 3-9).

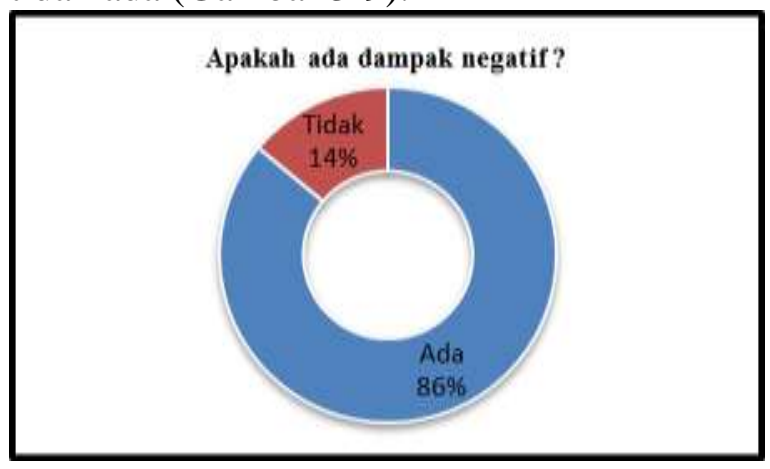

Gambar 3: Diagram dampak negatif

Berdasarkan total 43 narasumber, dampak yang dirasakan diantaranya adalah seperti berikut:

\begin{tabular}{|l|} 
Dampak berupa jalan macet \\
Yang tidak \\
merasakan dampak \\
Yang merasakan \\
Dampak \\
$100 \%$
\end{tabular}

Gambar 4: Diagram dampak berupa jalan macet

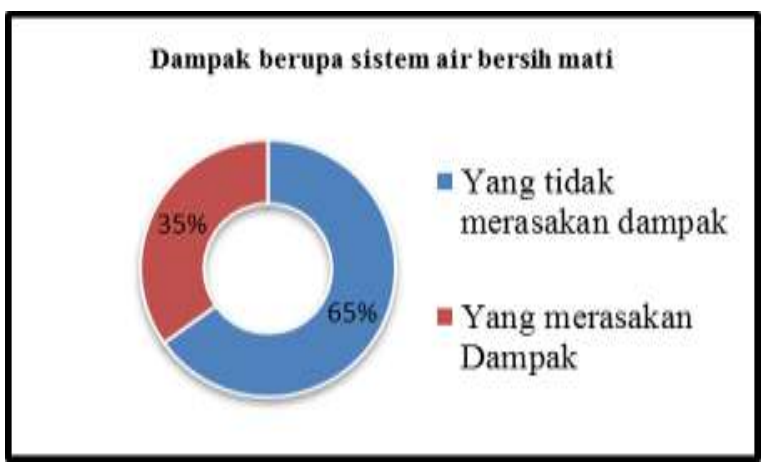

Gambar 5: Diagram dampak berupa sistem air bersih mati
Dampak berupa penurunan pendapatan

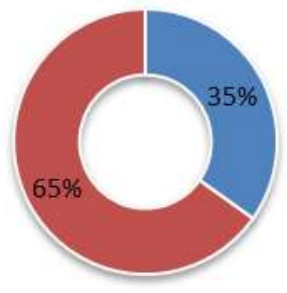

Yang tidak merasakan dampak

- Yang merasakan Dampak

Gambar 6: Diagram dampak berupa penurunan pendapatan

Menurut ibu Nila pemilik usaha rendang di lokasi pekerjaan, mengatakan penurunan pendapatan mencapai 40-50\% dikarenakan akses jalan yang menuju warungnya tertutup dan peletakan material bangunan mencapai 8 bulan tidak ada penanganan dari pihak kontraktor.

Dampak berupa kesulitan akses jalan

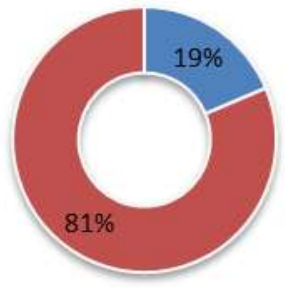

- Yang tidak merasakan dampak

- Yang merasakan

Dampak

Gambar 7: Diagram dampak berupa kesulitan akses jalan

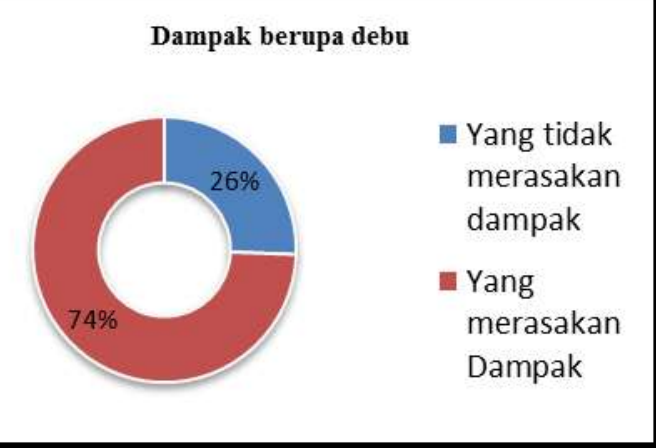

Gambar 8: Diagram dampak berupa debu

Hal yang paling dikeluhkan masyarakat adalah debu dari aktivitas pembangunan yang sangat mengganggu warga. Debu-debu tersebut masuk ke dalam rumah warga sehingga sulit untuk dibersihkan. Menurut bapak Syamsuir, yang 
memiliki usaha rumah makan mengalami penurunan jumlah pelanggan sangat drastis.

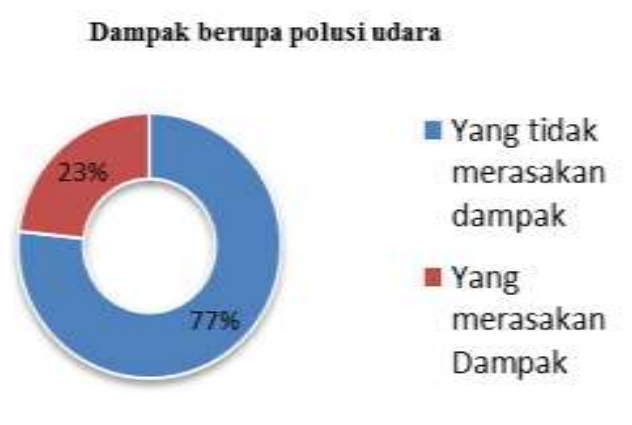

Gambar 9: Diagram dampak berupa polusi udara

2. Apakah ada dampak positif dari pelaksanaan rehabilitasi drainase irigasi pada jalan AlaiBypass?

Hasil wawancara kepada 50 narasumber, 50 orang menjawab ada, meskipun pekerjaan sedang dalam tahap konstruksi (Gambar 10).

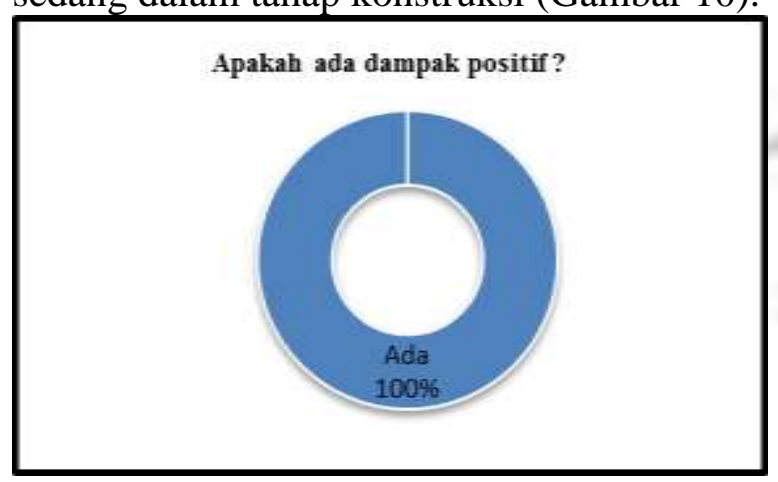

\section{Gambar 10: Diagram dampak positif}

Menurut bapak Marzuki pemilik usaha warung eceran, dampak positif yang dirasakan adalah keadaan jalan yang ramai sehingga banyak pengunjung yang datang untuk berbelanja.

3. Apakah ada peningkatan kesejahteraan selama kegiatan berlangsung?

Hasil wawancara kepada 50 narasumber, 22 orang menjawab ada, 10 orang menjawab kurang merasakan peningkatan dan 18 orang menjawab tidak (Gambar 11).

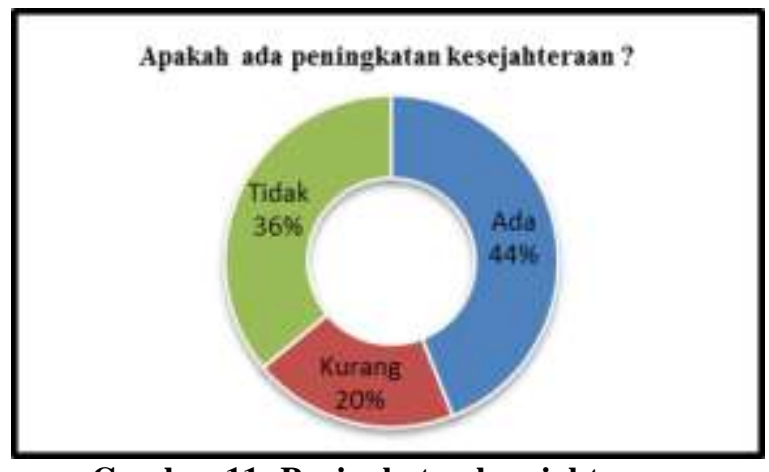

Gambar 11: Peningkatan kesejahteraan

4. Apakah pada saat pelaksanaan pekerjaan mengganggu aktivitas masyarakat?

Hasil wawancara kepada 50 narasumber, 18 orang menjawab ada dan 32 orang menjawab tidak ada (Gambar 12).

Apakah pembangunan menggangu aktivitas warga?

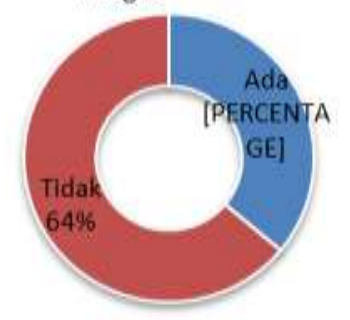

Gambar 12: Gangguan aktivitas

Berdasarkan kesaksian dari ibu Nilla pemilik salah satu warung eceran yang berada di lokasi pekerjaan pada saat masa konstruksi, akses jalan menjadi susah karena tidak disediakan jembatan sementara untuk penghubung rumah warga ke jalan raya sehingga mobilnya parkir di badan jalan.

5. Hal buruk apa saja yang terjadi selama masa konstruksi?

Hasil wawancara kepada 50 narasumber, 29 orang menjawab ada dan 21 orang menjawab tidak ada (Gambar 13). 


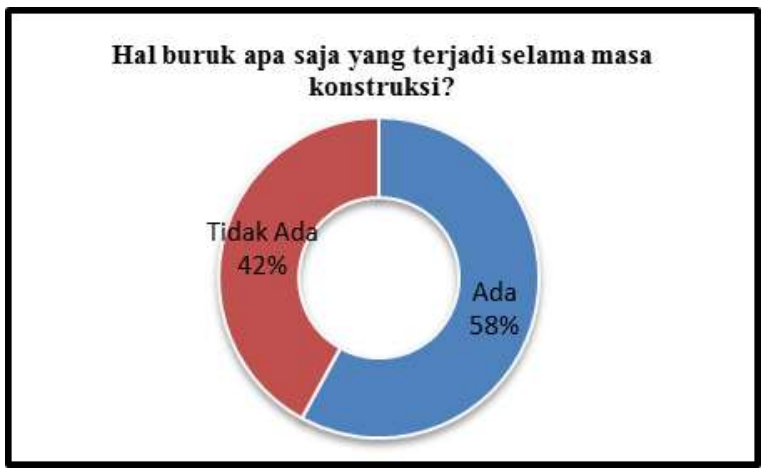

Gambar 13: Hal buruk selama konstruksi

Hal buruk yang sering terjadi berdasarkan hasil wawancara adalah kecelakaan lalu-lintas. Menurut bapak Ibnu, sering sekali terjadi kecelakaan lalu-lintas pada malam hari, dikarenakan pengendara tidak melihat meterial (pasir dan batu) yang di letakkan di pinggir jalan.

6. Hal baik apa saja yang terjadi selama masa konstruksi?

Hasil wawancara kepada 50 narasumber, 50 orang menjawab ada (Gambar 14).

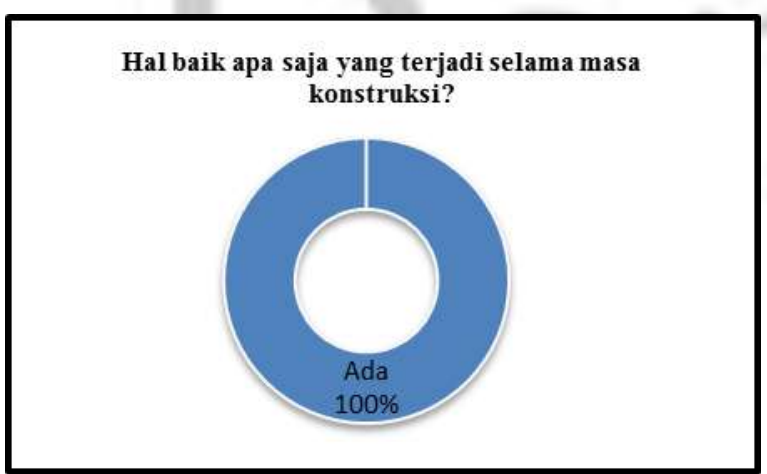

Gambar 14: Hal baik selama konstruksi

Berdasarkan hasil wawancara, hal baik yang dirasakan masyarakat secara bertahap dengan selesainya pekerjaan berupa jalanan menjadi ramai, aliran drainase lancar, ekonomi masyarakat menjadi hidup dan semakin banyak masyarakat yang membuka usaha mikro di sepanjang jalan.

7. Apa saja keluhan masyarakat pada pekerjaan drainase irigasi di jalan AlaiBypass?
Hasil wawancara kepada 50 narasumber, 12 orang menjawab terdapat keluhan dan 38 orang menjawab tidak ada (Gambar 15).

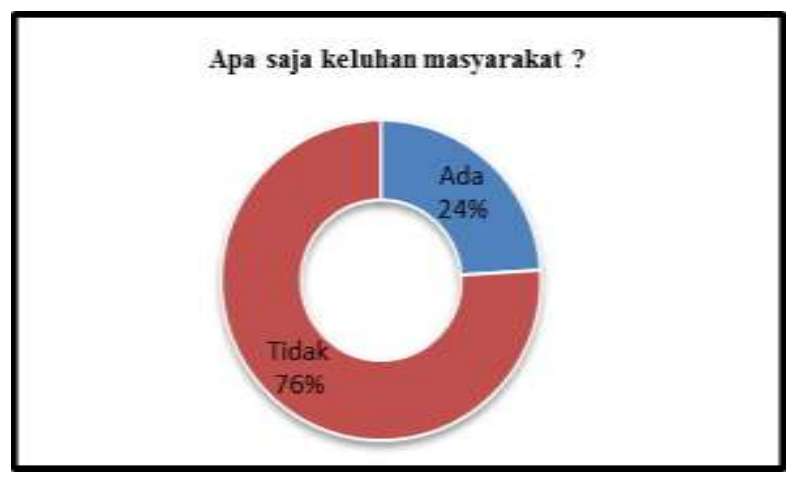

Gambar 15: Keluhan masyarakat

8. Apakah pekerjaan ini memiliki kontribusi terhadap rehabilitasi lingkungan?

Dari hasil wawancara kepada 50 narasumber, 13 orang menjawab ada dan 37 orang menjawab tidak ada (Gambar 16).

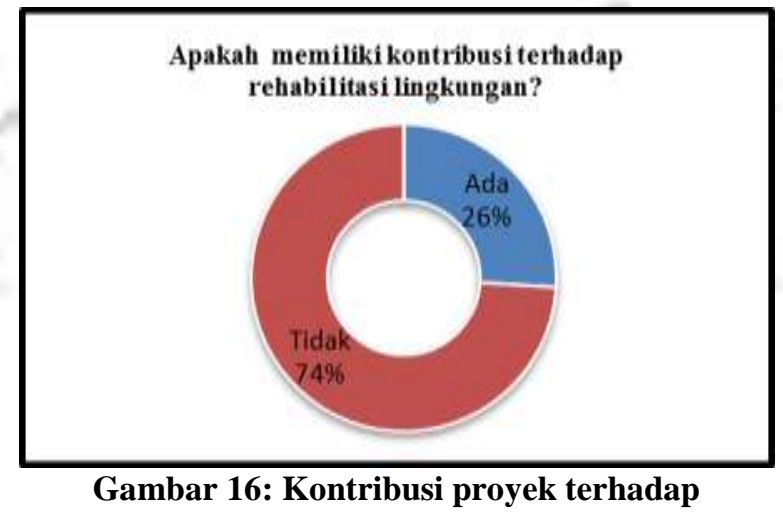
rehabilitasi lingkungan

Tidak banyak kontribusi yang dirasakan masyarakat terkait rehabilitasi lingkungan yang dilakukan oleh pihak kontraktor. Menurut ibu Eli pemilik usaha warung eceran menyatakan bahwa usaha dari pihak kontraktor melakukan penyiraman debu yang berada di jalan dengan menggunakan eskavator dengan tujuan untuk mengurangi debu yang berterbangan.

9. Apakah ada upaya untuk mengatasi kerugian yang ditimbulkan?

Hasil wawancara kepada 50 narasumber, 50 orang menjawab tidak ada (Gambar 17). 


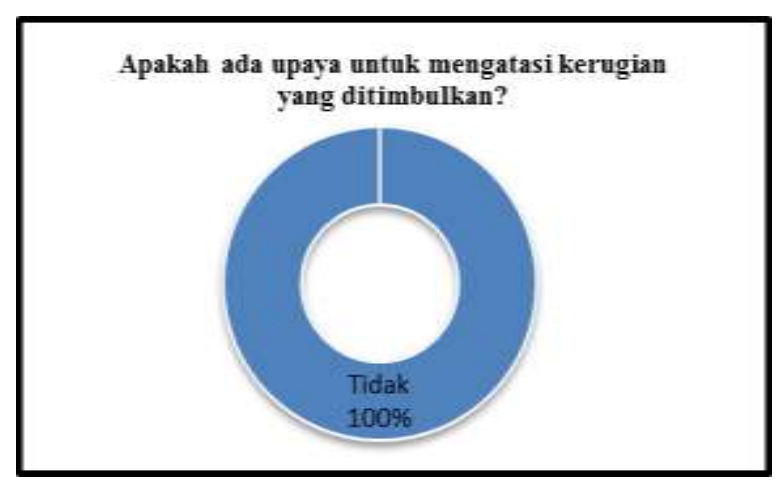

Gambar 17: Upaya untuk mengatasi kerugian

10. Apakah kegiatan pekerjaan ini kedepan menguntungkan bagi masyarakat yang berada disekitar drainase?

Hasil wawancara kepada 50 narasumber, 50 orang menjawab menguntungkan (Gambar 18).

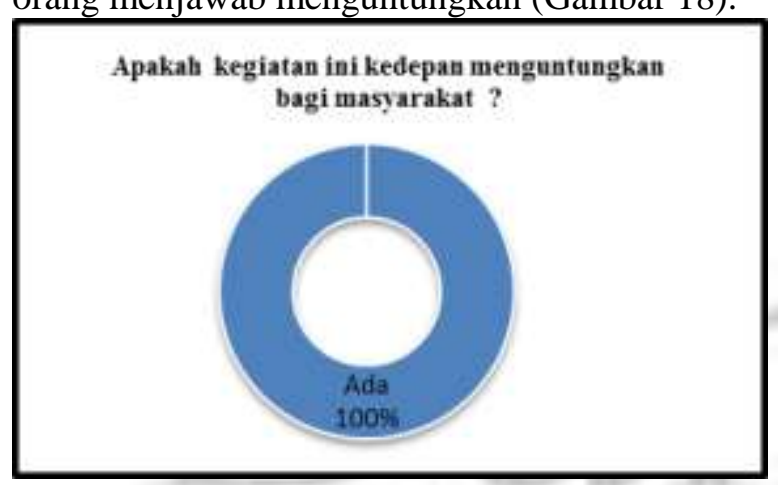

Gambar 18: Keuntungan ke depan bagi masyarakat

\section{Dampak yang terjadi pada kegiatan}

Berdasarkan hasil wawancara dan hasil pengamatan di lokasi kegiatan ada dampak positif seperti kesempatan kerja dan berfungsinya drainase secara optimal, serta banyak dampak negatif yang terjadi mengingat penyelanggaraan kegiatan ini tanpa disertai dengan pengaturan dokumen Amdal.

\section{Dampak penurunan kualitas udara}

Dampak yang dirasakan masyarakat adalah penurunan kualitas udara dengan meningkatnya kandungan debu. Kandungan debu di udara tidak hanya berasal dari polusi kendaraan angkut dan bahan material yang diangkutnya, tetapi juga berasal dari pengoperasian alat berat eksavator (Gambar 19).

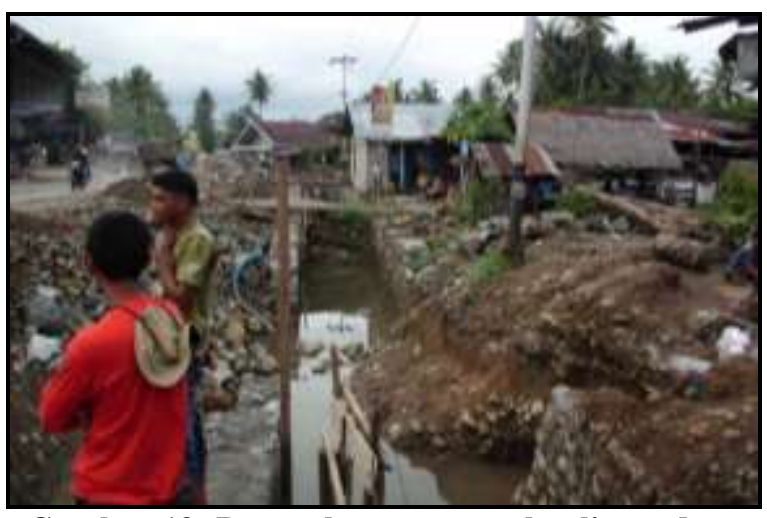

Gambar 19: Dampak penurunan kualitas udara

\section{Dampak kemacetan lalu-lintas}

Masyarakat mengalami dampak buruk dari kegiatan ini, salah satunya berupa kemacetan lalu-lintas. Kemacetan terjadi di sepanjang jalan dikarenakan aktivitas pekerjaan seperti penurunan material di tepi jalan, penimbunan bahan material yang memakai badan jalan, aktivitas alat berat eksavator sehingga pengguna jalan harus berbagi ruas jalan dengan aktivitas kegiatan. Menurut bapak Ibnu, kemacetan sering terjadi pada sekitar jam 09.00 WIB dan jam 18.00 WIB (Gambar 20-23).

Kemacetan ini memiliki dampak positif yaitu sebagai sarana promosi sesaat untuk toko-toko yang berada di tepi jalan pada saat pengendara berhenti, ujar ibu Nila pemilik toko rendang.

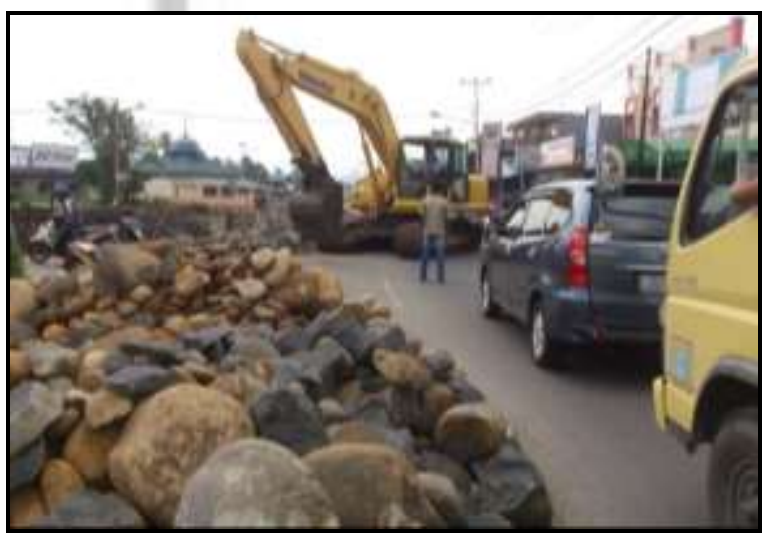

Gambar 20: Dampak kemacetan akibat aktivitas pekerjaan 


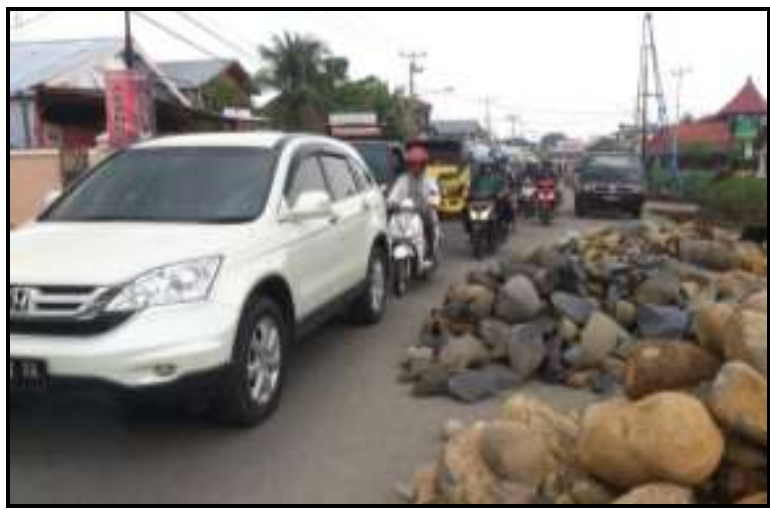

Gambar 21: Dampak kemacetan akibat tumpukan material

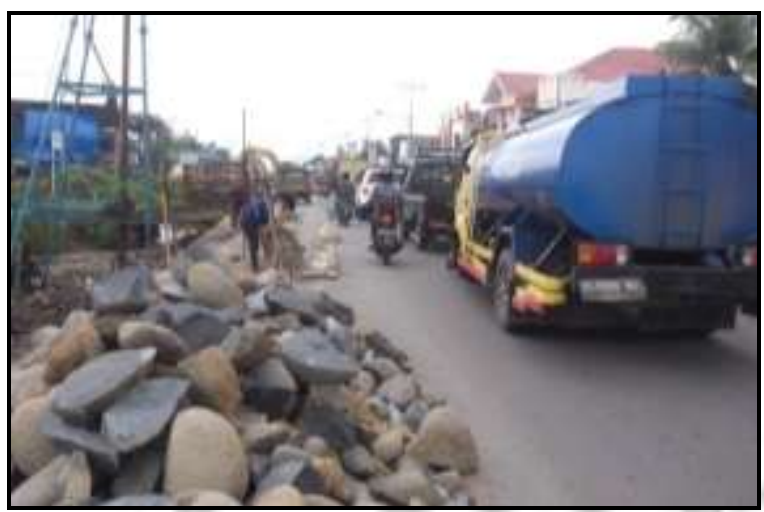

Gambar 22: Dampak kemacetan akibat tumpukan material

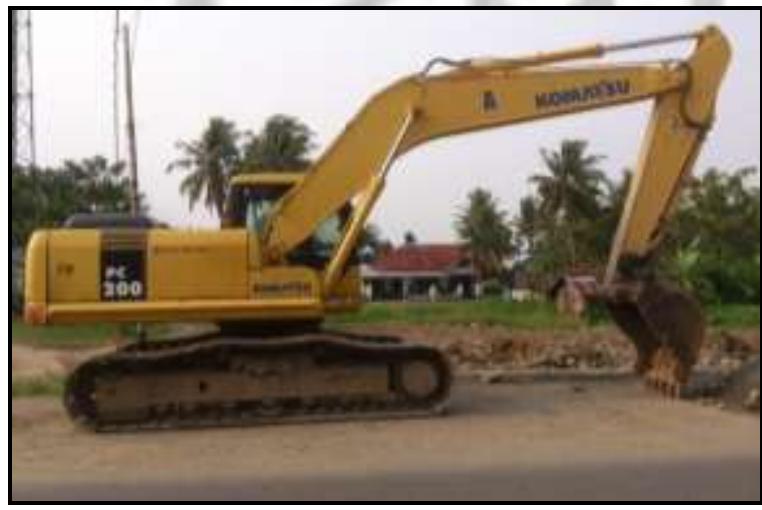

Gambar 23: Dampak kemacetan akibat parkir eksavator di jalan

\section{Dampak kesempatan kerja}

Keberlangsungan pekerjaan jalan Alai-Bypass berdampak positif bagi masyarakat sekitar berupa kesempatan kerja. Menurut ibu Nila, banyak pemuda yang dipekerjakan sebagai pengatur lalu-lintas dan pengamanan lalu lintas.

\section{Dampak penurunan kualitas air}

Penurunan kualitas air Irigasi Gunung Nago pada jalan Alai-Bypass disebabkan faktor peningkatan kekeruhan dan pelumpuran. Berdasarkan hasil wawancara menurut bapak Syamsuir, penurunan kualitas air juga terjadi pada aliran air PDAM dan air sumur (Gambar 24).

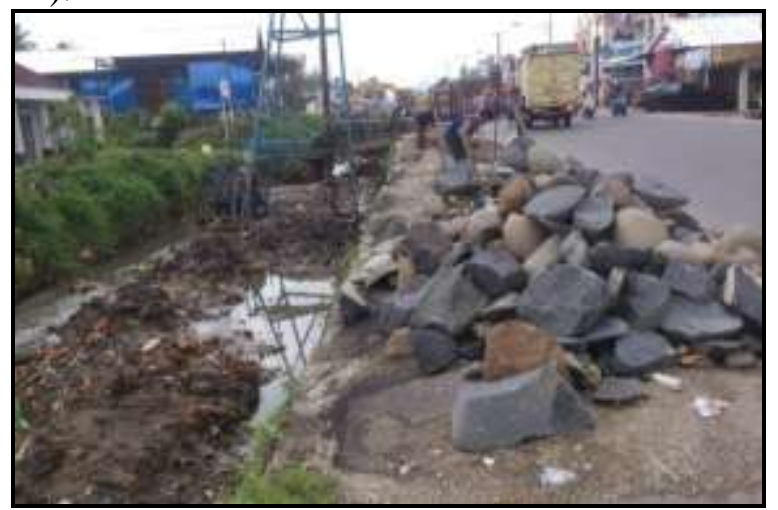

Gambar 24: Dampak penurunan kualitas air di drainase

\section{Dampak aksesbilitas masyarakat}

Akses jalan dari perumahan warga menuju jalan raya menjadi terganggu, warga yang memiliki kendaraan seperti mobil terpaksa parkir di tepi jalan karena tidak tersedianya jembatan darurat menuju masing-masing rumah penduduk (Gambar 25). Menurut bapak Mislan, hal ini sangat mengganggu warga yang memiliki aktifitas yang padat karena harus parkir jauh dari rumahnya.

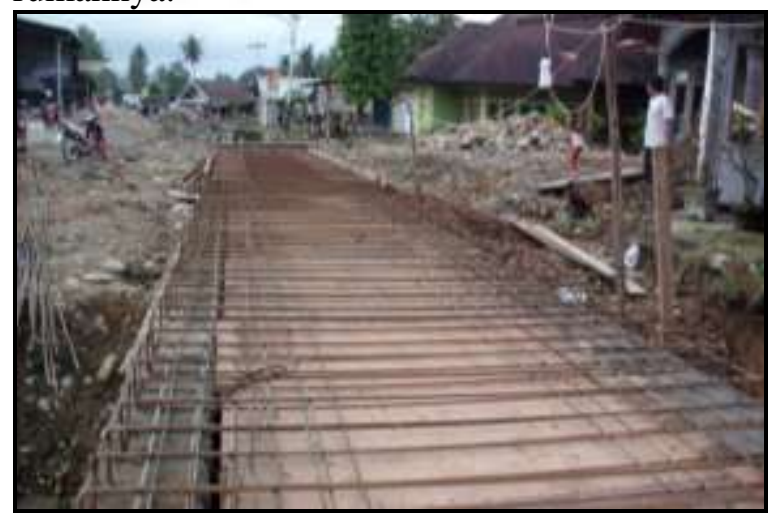

Gambar 25: Dampak aksesbilitas masyarakat terganggu

\section{Dampak aktifitas ekonomi masyarakat}

Seiring pelaksanaan pekerjaan berlangsung sebagian warga masyarakat yang memiliki usaha mengaku mengalami penurunan pendapatan 
karena wilayah ini menjadi tidak produktif lagi (Gambar 26).

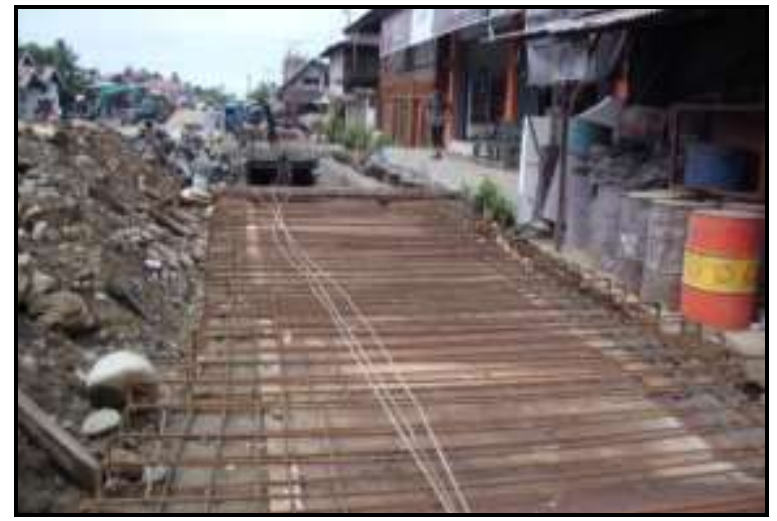

Gambar 26: Dampak aktifitas ekonomi masyarakat terganggu

Setelah prasarana jalan dan drainase secara bertahap selesai dilaksanakan, masyarakat lebih banyak membuka usaha mikro seperti membuka berbagai macam toko karena daerah ini menjadi jalan utama untuk dilalui kendaraan. Perubahan ini membawa dampak positif bagi masyarakat di sekitar jalan Alai-Bypass dan meyakini akan menguntungkan kedepannya (Gambar 27-30).

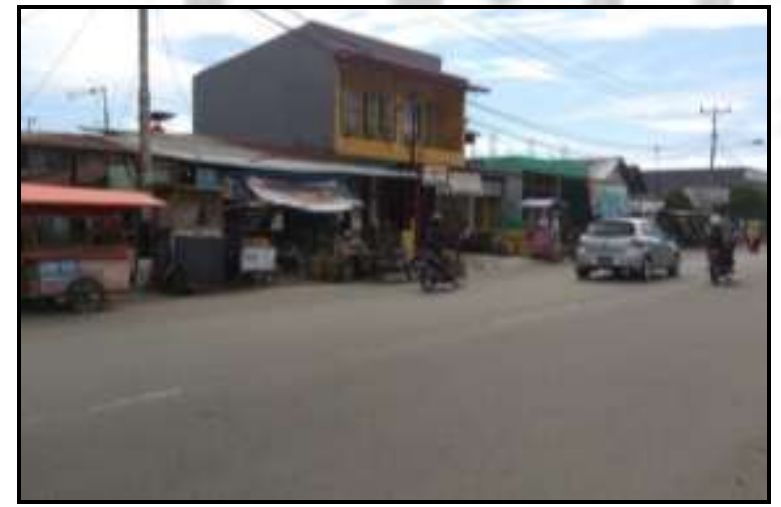

Gambar 27: Dampak aktifitas ekonomi masyrakat meningkat

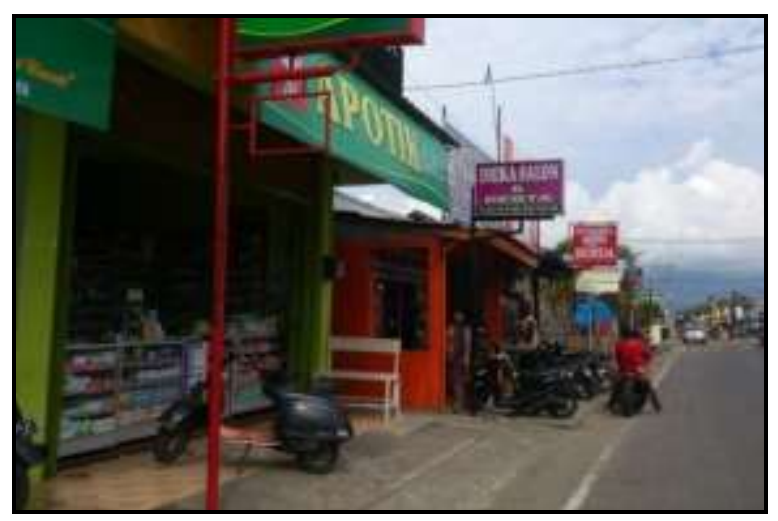

Gambar 28: Dampak aktifitas ekonomi masyarakat meningkat

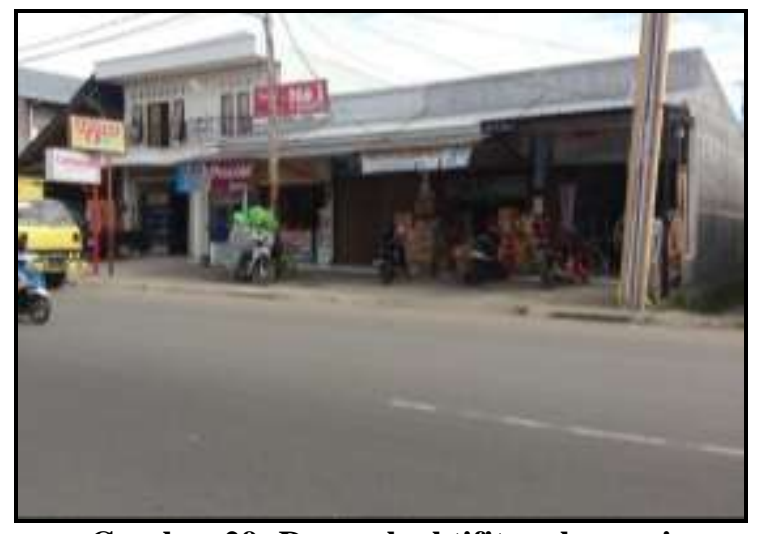

Gambar 29: Dampak aktifitas ekonomi masyarakat meningkat

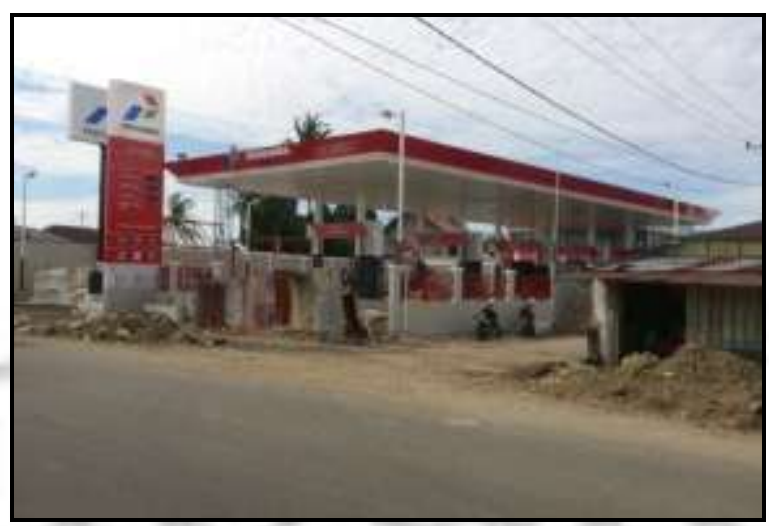

Gambar 30: Dibangunnya SPBU menandakan daerah ini berkembang

\section{Pengelolaan rehabilitasi drainase jika menerapkan Amdal}

Pengelolaan yang bisa dilakukan untuk mengurangi dampak antara lain sebagai berikut:

- Pengaturan lalu-lintas dengan baik bagi kendaraan yang melewati jalan Alai-Bypass.

- Untuk mencegah peningkatan emisi (gas buang), alat berat dan kendaraan angkut yang dioperasikan dalam kondisi baik dan dilengkapi dengan knalpot yang memadai.

- Pelaksana kegiatan menutup bak kendaraan angkut dengan terpal atau melakukan pengaturan bahan material yang diangkut tidak melebihi dari tinggi dinding kendaraan yang dioperasikan.

- Menimbun bahan material secukupnya sehingga tidak mengganggu arus kendaraan. 
- Pelaksana kegiatan menyiram ruas jalan lingkungan yang dilalui kendaraan angkut selama tahap konstruksi.

- Menyiapkan jembatan sementara untuk kepentingan warga pada tempat-tempat tertentu.

\section{Rekapitulasi hasil wawancara}

Berdasarkan hasil wawancara kepada masyarakat yang bertempat tinggal di sekitar pekerjaan rehabilitasi drainase didapatkan hasil seperti Tabel 2.

\section{SIMPULAN}

Dengan membandingkan dokumen kontrak pekerjaan, pengerjaan dilapangan dan berdasarkan literatur yang ada, tulisan ini memberikan kesimpulan bahwa :

a. Kegiatan rehabilitasi drainase tidak menerapkan dokumen Amdal, sehingga penyedia jasa/kontraktor tidak optimal untuk mengurangi dampak buruk di lingkungan pekerjaan.

b. Selama pelaksanaan, kegiatan ini menimbulkan berbagai dampak buruk bagi masyarakat seperti penurunan kualitas udara, kemacetan lalu lintas, penurunan kualitas air, aksesbilitas masyarakat, penurunan aktivitas ekonomi masyarakat. Dampak positif berupa kesempatan kerja,

Tabel 2 : Rekapitulasi hasil wawancara

\begin{tabular}{|c|c|c|c|c|c|}
\hline \multirow{2}{*}{ No. } & \multirow{2}{*}{ Pertanyaan } & \multicolumn{3}{|c|}{ Jawaban } & \multirow{2}{*}{ Keterangan } \\
\hline & & Ada & Kurang & Tidak & \\
\hline 1 & $\begin{array}{l}\text { Apakah ada dampak negatif dari } \\
\text { pelaksaan drainase pada jalan Alai- } \\
\text { Bypass? }\end{array}$ & 47 & - & 3 & $\begin{array}{l}\text { Penurunan pendapatan, debu dan } \\
\text { kesulitan akses }\end{array}$ \\
\hline 2 & $\begin{array}{l}\text { Apakah ada dampak positif dari } \\
\text { pelaksaan drainase pada jalan Alai- } \\
\text { Bypass? }\end{array}$ & 50 & - & - & $\begin{array}{l}\text { Kesempatan kerja, membantu } \\
\text { promosi }\end{array}$ \\
\hline 3 & $\begin{array}{l}\text { Apakah ada peningkatan } \\
\text { kesejahteraan selama kegiatan } \\
\text { berlangsung? }\end{array}$ & 22 & 10 & 18 & Secara umum tidak ada \\
\hline 4 & $\begin{array}{l}\text { Apakah pada saat masa konstruksi } \\
\text { pembangunan mengganggu aktivitas } \\
\text { warga? }\end{array}$ & 18 & - & 32 & Aksesibilitas warga terganggu \\
\hline 5 & $\begin{array}{l}\text { Hal buruk apa saja yang terjadi } \\
\text { selama masa konstruksi? }\end{array}$ & 29 & - & 21 & $\begin{array}{l}\text { Kemacetan dan kecelakaan lalu } \\
\text { lintas }\end{array}$ \\
\hline 6 & $\begin{array}{l}\text { Hal baik apa saja yang terjadi selama } \\
\text { masa kosntruksi? }\end{array}$ & 50 & - & - & $\begin{array}{l}\text { Selesai pekerjaan bertahap, jalan } \\
\text { menjadi ramai, aliran drainase } \\
\text { lancar }\end{array}$ \\
\hline 7 & $\begin{array}{l}\text { Apa saja keluhan masyarakat pada } \\
\text { rehabilitasi drainase jalan Alai- } \\
\text { Bypaas? }\end{array}$ & 12 & - & 38 & $\begin{array}{l}\text { Peletakan material di depan } \\
\text { usaha warga dalam waktu lama. }\end{array}$ \\
\hline 8 & $\begin{array}{l}\text { Apakah proyek memiliki kontribusi } \\
\text { terhadap rehabilitasi lingkungan? }\end{array}$ & 13 & - & 37 & $\begin{array}{l}\text { Penyiraman jalan berdebu } \\
\text { dengan menggunakan eksavator }\end{array}$ \\
\hline 9 & $\begin{array}{l}\text { Apakah ada upaya dari kontraktor } \\
\text { untuk mengatasi kerugian yang } \\
\text { ditimbulkan? }\end{array}$ & - & - & 50 & Tidak ada \\
\hline 10 & $\begin{array}{l}\text { Apakah kedepannya menguntungkan } \\
\text { bagi masyarakat yang berada di } \\
\text { sekitar kegiatan? }\end{array}$ & 50 & - & - & Menguntungkan \\
\hline
\end{tabular}


c. Jalan Alai-Bypass kedepan akan meningkatkan kesejahteraan masyarakat yang berada disekitarnya.

\section{DAFTAR PUSTAKA}

Keputusan Menteri Lingkungan Hidup Nomor 17 tahun 2001, "Jenis usaha dan/atau kegiatan yang wajib dilengkapi dengan Amdal"

Departemen Pemukiman dan Prasarana Wilayah, Direktorat Jenderal Sumber Daya Air. 2001. "Perbaikan Sungai Anai - Kandis". PT Bina Lingkungan Lestari : Padang.

Dinas Pengelolaan Sumber Daya Air. 2014. "Pengembangan dan Pengelolaan Jaringan Irigasi, Rawa dan Jaringan Pengairan Lainnya". PT Guna Karya Nusantara : Bandung.
Erlangga, Dicky. 2014. "Pembangunan Infrastruktur Jalan dan Jembatan yang Berwawasan Lingkungan". Pengelolaan Sumberdaya Alam Dan Lingkungan Fakultas Teknik Universitas Bengkulu : Bengkulu.

Masruri Irsal, Ridho. 2008. "Perencanaan bangunan dengan mempertimbangkan aspek energi dan lingkungan". Departemen Arsitektur Fakultas Teknik Universitas Indonesia : Jakarta.

Pedoman Konstruksi dan Bangunan. 2009. "Pedoman Pelaksanaan Lingkungan Hidup Bidang Jalan". Departemen Pekerjaan Umum Direktorat Jenderal Bina Marga.

Istijono B. 2014. "Pembangunan Pengendali Banjir yang Berwawasan Lingkungan, studi kasus Pengendali Banjir Batang Anai, Sumatera Barat” Jurnal Ilmiah, Fakultas Teknik, Universitas Andalas, Seri Energi dan Ekologi Volume 21 Nomor 2 Juli 2014. 